\title{
ANALYSIS ON THE TOTAL QUALITY MANAGEMENT (TQM) PRACTICES TOWARDS BUSINESS PERFORMANCE; A CASE STUDY
}

\section{Muhammad Isradi Zainal'), Wahyu Ismail Kurnia*1, Kuswandi Arifin"), and Seherdi Siman*)}

${ }^{*}$ Department of Industrial Engineering, Faculty of Industrial Technology, Universitas Balikpapan

J1. Pupuk Raya, Kel. Gunung Bahagia, Kec. Balikpapan Selatan, Balikpapan 76114, Indonesia

${ }^{* *}$ Department of Industrial Engineering, Faculty of Industrial Technology, Universitas Islam Indonesia

Jl. Kaliurang, Km. 14.5, Kec. Ngemplak, Kab. Sleman, Daerah Istimewa Yogyakarta 55584 , Indonesia

\begin{abstract}
The improvement of company management quality to achieve competitive advantage must be appropriate in the term of applying the concept or strategy of improvement, because it can affect the company's success in competition with its competitors. Total Quality Management (TQM) is one of the concepts which is in regard with improving the quality of company management by considering almost all company aspects. It is proven through the claim of most academics and practitioners who say that TQM can improve company's business performance. This research aims to find out the implications of TQM practices on the business performance of PT. XYZ which is engaged in cement business. There are 10 TQM indicators and 3 company's business performance indicators used, as well as 250 respondents who involved in this research. The approach of Structural Equations Modeling (SEM) is used in data processing and analysis. The software used are SPSS version 22 and SPSS-AMOS version 21. The results show that the practices of TQM have a positive effect on company's business performance significantly. Moreover, each constructs of TQM variables and company's business performance show the adequate level of validity and is declared as capable in representing each variable. After all, this research is adequate to prove that TQM practices can significantly bring positive impact towards the business performance of XYZ Ltd.
\end{abstract}

Keywords: business performance, competitive advantage, management quality, structural equations modeling (SEM), total quality management (TQM)

\begin{abstract}
Abstrak: Perbaikan kualitas manajemen perusahaan untuk mencapai keunggulan kompetitif, harus tepat dalam penerapan konsep atau strategi perbaikan, sebab dapat mempengaruhi keberhasilan perusahaan dalam persaingan antar kompetitor. Total Quality Management (TQM) merupakan salah satu konsep perbaikan kualitas managemen perusahaan yang mempertimbangkan hampir semua aspek pada perusahaan. Terbukti sebagian besar akademisi dan praktisi mengatakan bahwa TQM mampu memperbaiki kinerja bisnis perusahaan. Penelitian ini bermaksud untuk mengetahui implikasi praktek TQM terhadap kinerja bisnis PT. XYZ yang bergerak dibidang semen. Ada 10 indikator $T Q M$ dan 3 indikator kinerja bisnis perusahaan yang digunakan dan 250 responden yang terlibat dalam penelitian ini. Pengolahan dan analisis data menggunakan pendekatan Structural Equations Modelling (SEM) dan softwere yang digunakan adalah SPSS versi 22 dan SPSS-AMOS versi 21. Hasil penelitian menunjukan bahwa praktek TQM memiliki efek positif secara signifikan terhadap kinerja bisnis perusahaan. Sementara masingmasing konstruk dari variabel TQM dan kinerja bisnis perusahaan menunjukan tingkat validitas yang memadai dan dinyatakan mampu merepresentasikan masing-masing variabel. Akhirnya, penelitian ini mampu membuktikan bahwa praktek TQM berdampak positif secara signifikan terhadap kinerja bisnis PT. XYZ. Secara teoritis, memberikan nilai tambah atas pengetahuan tentang hubungan praktek TQM dengan kinerja bisnis perusahaan dalam mencapai keunggulan kompetitif.
\end{abstract}

Kata kunci: keunggulan kompetitif, kinerja bisnis, manajemen kualitas, structural equations modeling (SEM), total quality management (TQM)

\footnotetext{
${ }^{1}$ Corresponding author:

Email: wahyu.ismail.kurnia@uniba-bpn.ac.id
} 


\section{INTRODUCTION}

Rapid changes in the use of technology, social needs, and environmental aspects have become a major challenge for companies in maintaining and achieving competitive advantage in the last decade (Cancino et al. 2018). From economic aspect, companies face such an increasing pressure to maintain their competitiveness (Gherardini et al. 2017). At the global level, companies are getting attentions in terms of efficiency, quality, service, innovative customer loyalty program and political (Maheshwari and Vohra, 2015). As a result, traditional methods that are still used and preserved by most companies their activities are considered as irrelevant regarding the conditions of high competitive market today (Ibidunni et al. 2017). Company's awareness is needed to change their business activities to be more innovative and higher in quality so that they are able to get out from the failure to compete both in national and international level (Zakuan et al. 2010).

The success achieved by the company depends on the accuracy of strategy applied. This is the result of the soaring competition level and change in the business world, that the attention on improving the quality of company's activities becomes the key to successfully achieving competitive advantage. Companies cannot continuously maintain the quality of products without adopting the in-depth strategies and practical quality management. One of the prominent business strategy that has received attention from academics and practitioners in the last decade is Total Quality Management (TQM) (Jimoh et al. 2019; Panuwatwanich and Nguyen, 2017; Salas-Arbeláezet al. 2017; Sinha and Dhall, 2018). TQM is approved as the system that improve the performance of company organization (Khawarmahmood et al. 2014; Small et al. 2017), and strengthen company's position in reaching its competitive advantage (Li et al. 2018). Besides being able to increase profits, TQM also able to increase employee and customer satisfaction (Shafiq et al. 2019). Recent studies have shown that TQM positively influences the performance of manufacturing companies (Sahoo and Yadav, 2018) and services in India (Singh et al. 2018a). Then, a strong and significant correlation between TQM and company performance (Cetindere., 2015), as well as its positive effect on the performance of company employees (Wagimin et al. 2019). Most companies claim the positive relation between the implementation of TQM concept and company performance (Konecny and Thun, 2011); (AlDhaafri., 2016); (Sahoo and Yadav, 2017), yet provide not optimal results on its application in some other (Yang et al. 2009). The implementation of TQM cannot be successful unless employees are directly involved in the business process by attending courses and trainings to be more competent (Khanna and Gupta, 2014).

Companies must be aware since the beginning of how important it is to improve output quality because it is in direct touch with customer satisfaction and becomes the benchmark of company sustainability, with no exception for PT. XYZ, a manufacturing company which is the largest cement company in eastern Indonesia. Each year, the company is able to produce an average of 6 million tons of cement with 4 units of cement processing plants. Based on preliminary observations and interviews, a number of problems have been found; nonoptimal performance of employees, the lack of employees involvement in determining product distribution routes, uncompetitive product quality compared to similar products in the market resulted in vacant of stock in some particular area. As the largest cement manufacturer in eastern Indonesia, PT. XYZ is supposed to continuously improve the quality of company's inputs, processes, and outputs.

The practices of TQM is said to be successful depend on the company's seriousness and consistency continually. Related to the practices of TQM at PT. XYZ business performance, the result is not yet seen so far. Therefore, it is important to conduct research related to the impact of TQM practices on the business performance of PT. XYZ. To achieve the objectives, 10 TQM indicators are used, consisting of: focus on customers, obsession with quality, scientific approach, empowerment of employees, teamwork, continuous improvement, education and training, controlled freedom, unity of purpose, and involvement and empowerment of employees (Tjiptono and Diana, 2003; Gaspersz, 2001). Whereas, business performance consists of return on investment (ROI), market share, and sales growth (Syamsuddin, 1992; Lamb., 2001). This research is expected to be able to prove to what extent that the practices of TQM are impacted XYZ Ltd.'s performance in order to achieve competitive advantage, as well as to be a valuable input regarding the correlation between TQM practices and the performances of manufacture companies. By conducting this research, the results are expected to make a valuable contribution regarding the influence of TQM on company performance from the perspective of a manufacturing company, as well as to help academics and practitioners in TQM campaign for manufacturing 
companies. Therefore, the purpose of this research is to analyze to which extent that the adoption of TQM practices give an impact on PT. XYZ business performance. To achieve optimal results, this study using Structural Equation Modeling (SEM) approach.

\section{METHODS}

This research was held in PT. XYZ which located in Pangkep, South Sulawesi, started from March 2019 until August 2019. PT. XYZ is a manufacturing company which also the largest cement company in eastern Indonesia. Each year, the company is able to produce an average of 6 million tons of cement including 4 units of cement processing plants.

There are 2 (two) types of data used in this research, which are primary and secondary data. The primary data came from the questionnaires results. The questionnaires were distributed to 250 employees from top to the bottom management at PT. XYZ. In order to keep the research run in the efficient way, the researcher took the company's break time or employees free time to do the filling. The spreading of questionnaire was done by directly handed the form to each employee. Meanwhile, secondary data were obtained from the database of company personnel department, company performance reports, and relevant literature to support this research.

The process of collecting the data was done through several stages consisted of (1) Library research (literature research) and field research to capture the initial description of company's business performance condition, as well as preparing theresearch questionnaire. The questionnaire had two sections: section A which contained the description of demographic characteristic, and section $\mathrm{B}$ which contained the questions regarding the constructs of TQM and business performance. The constructs of TQM were focus on customers (X1.1), obsession with quality (X1.2), scientific approach (X1.3), employees empowerment (X1.4), teamwork (X1.5), continuous improvement (X1.6), education and training (X1.7), controlled freedom (X1.8), unity of purpose (X1.9), involvement and empowerment of employees (X1.10), while the constructs of business performance were Return on Investment (ROI) (Y1.1), market share (Y1.2), and sales growth (Y1.3). All questions were measured using Likert scale started from 1-5 (strongly disagree to strongly agree); (2)
Validation of measurement questionnaire items in form of questionnaires before being distributed to respondents by experts; (3) Direct distribution of validated questionnaires to respondents in total of 250 people.

This research used the approach of Structural Equation Modeling (SEM) model. SEM was used to estimate the relationship strength between variables in the proposed model. The choosing of SEM was based on the ability in managing, estimating, and describing the strength of the relationship and influence between variables in the proposed model (Maruyama, 1998; Abbas, 2020; Hair et al. 2010). Data processing was done after the process of data collection had been completed. The process were (1) demographic characteristics of the respondents involved in this study; (2) test the basic assumptions of SEM modeling; (3) test confirmatory factor analysis (CFA). It was used to determine the construct consistency and adequacy of the proposed hypothesis model with the standard value above 0.50 (> 0.50); (4) SEM analysis to test the relationship between TQM practices and company business performance.

\section{Hypothesis}

The model of this research consisted of two latent variables including Total Quality Management (TQM) and Business Performance (BP). Several studies reveal that the effect of TQM practices on company business performance can be measured through a number of aspects, such as return on investment, market share, and sales growth (Delić set al. 2014; Jaca and Psomas, 2015), finance and markets, effectiveness, customers satisfaction, and employees (Mensah et al. (2012), low operating costs, increased productivity, efficiency, and innovation (Bolboli and Reiche, 2013).

To get a vivid picture of TQM practice of, 10 indicators were used. Furthermore, 3 indicators were used for company's business performance, including return on investment, market share, and sales growth. The reasons for choosing these 3 indicators were: (1) the company's financial condition can be clearly illustrated through the return on investment; (2) sales growth is determined on customer satisfaction, efficiency and effectiveness in using resources, quality improvement through product development and innovation, and of course sales growth determines whether the company's business performance is good or not; and (3) the good condition of company's business performance is illustrated by 
the increase in company's market share, which has a direct impact on the level of sales and increases in profitability. The description of each indicator could be seen in Table 1. To support the proposed hypothesis, conceptual model of this research could be seen in Figure 1. Meanwhile, Figure 2 presents the complete specifications of the proposed model.

Through this research, the expected result is the significantly positive impact of TQM on PT. XYZ's company performance. Thus, TQM has once again proven to be effective and can be the choice for companies in improving their business performance. Then, based on the background description and frame of mind, the proposed research hypothesis is:

H1: TQM practices give positive effects to company's BP significantly.

\section{RESULTS}

\section{Demographic Characteristic}

After the text edit has been completed, the paper is ready for the template. Duplicate the template file by using the Save As command, and use the naming convention prescribed by your conference for the name of your paper. In this newly created file, highlight all of the contents and import your prepared text file. You are now ready to style your paper; use the scroll down window on the left of the MS Word Formatting toolbar.

\section{Basic Assumptions for SEM Modeling}

One of SEM's advantages is its capability to modeling the correlation between complex and multivariate variables. A SEM model is considered good if it meets the basic assumptions, such as sample size and data normality. Samples size also important in SEM modeling. The bigger sample size is the better for SEM modeling (Arbuckle, 2013; Wagimin et al. 2019). To accomplish this, the research used 250 respondents involved in data collection with $100 \%$ response rate. Thus, the sample size of this study has met the basic assumptions of SEM. Furthermore, normality testing was built upon the value of critical ratio skewness and critical ratio kurtosis based on the conditions of \pm 2.58 . According to (Singh and Sharma, 2016), if the value of kurtosis and skewness is less than \pm 2.58 , the normality testing then could be accepted, or in the other words, the data is normally distributed. Based on the testing result, the research data were normally distributed because critical ratio skewness and critical ratio kurtosis in multivariate was $-0,128$ which showed that the value was around \pm 2.58 .

Table 1. Indicators of TQM and Company's BP

\begin{tabular}{lll}
\hline Latent Variable & Indicators & Sources \\
\hline $\begin{array}{l}\text { Total Quality Management } \\
\text { (TQM) }\end{array}$ & Focus on customers (X1.1) & (Wagimin et al. 2019; Tjiptono and \\
& & Diana, 2003); \\
& Obsession with quality (X1.2) & Kumar., 2011; Prajogo and Sohal, \\
& Scientific approach (X1.3) & 2006; del Alonso-Almeida., \\
& Employees empowerment (X1.4) & 2015; Jaca and Psomas, 2015; \\
& Parvadavardini., 2016)
\end{tabular}




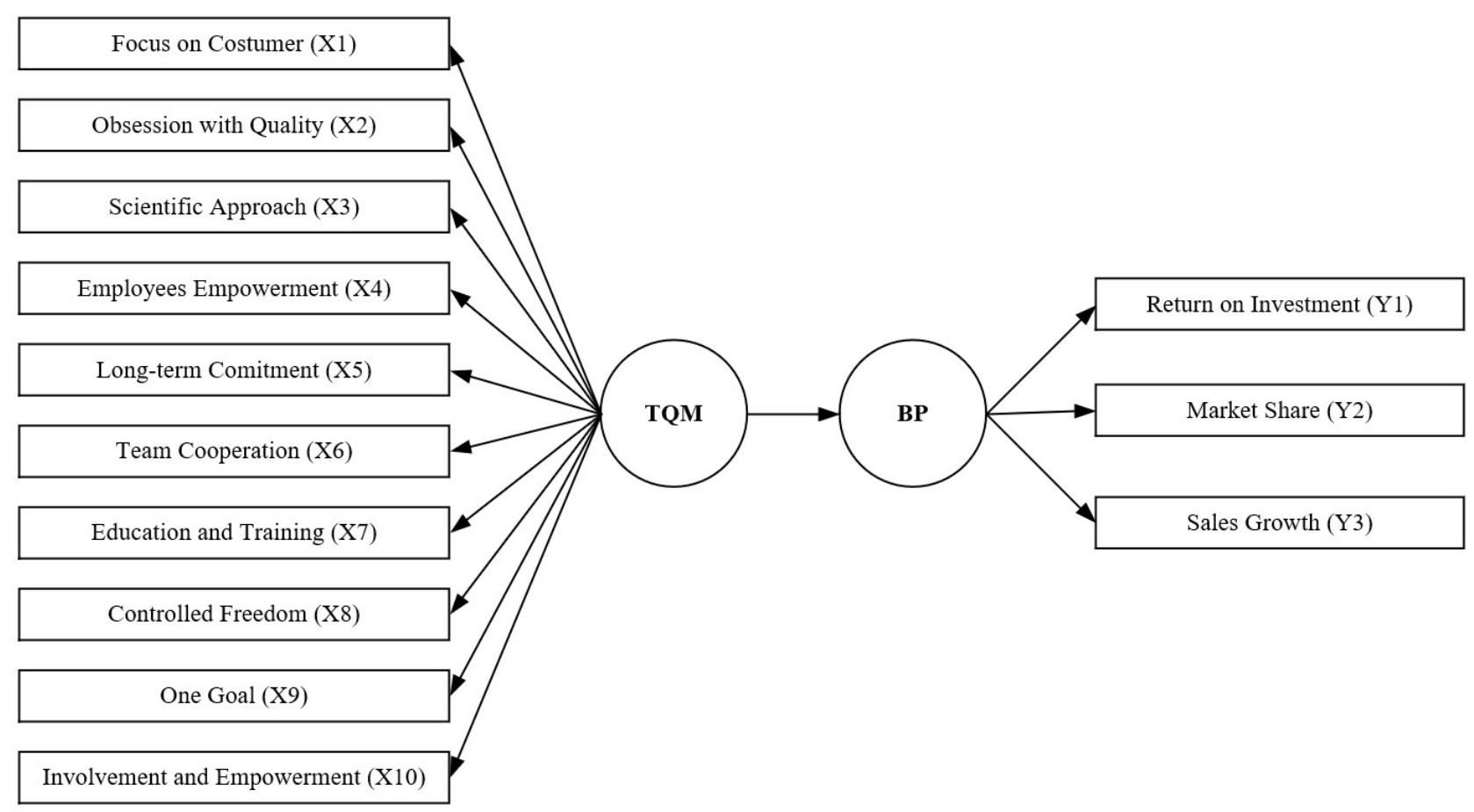

Figure 1. Conceptual model which connecting TQM to BP

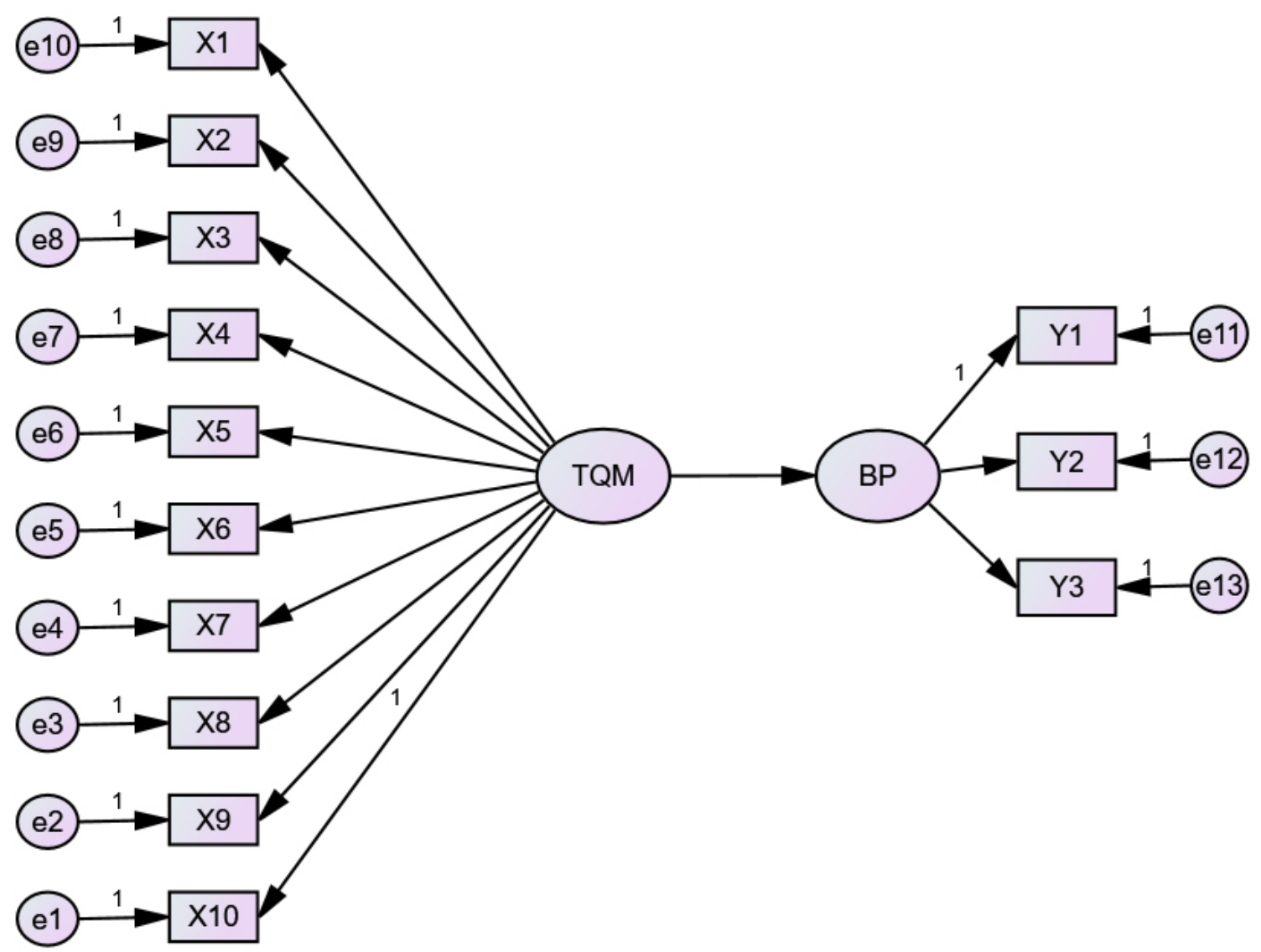

Figure 2. SEM model and contruct specification 


\section{Confirmatory Factor Analysis (CFA)}

CFA was aimed to test the level of construct adequacy and feasibility as well as the proposed hypothesis model. From testing result presented in Figure 3 could be seen that all constructs had significant level above 0.50 . Thus could be concluded that all indicators were adequate and feasible for SEM modeling.

\section{SEM Model Test}

The model could be said as fit and acceptable when it meets the number of standard assessment criteria. Goodness of fit criteria which used in this research contained CMIN/DF (Chi-square Fit Index divided by Degrees of Freedom), GFI (Goodness-of-Fit Index), AGFI (Adjusted GFI), CFI (Comparative fit index), and RMSEA (Root Mean Square Error of Approximation). Based on the test result as presented in Figure 3 shown that the model was considered fit and had a much fine compatibility level. It was proven by the testing result was able to meet all of goodness of fit assessment criteria.

\section{Validity and Reliability}

The test of validity and reliability in this research was based on standardized factor loadings above 0.50 (Hair et al. 2010). If the standardized factor loadings were less than 0.50 , then it was declared as invalid, vice versa. The test results showed that standardized factor loadings for all items were above 0.50 , meant that the constructs in this study were valid. Furthermore, tested data reliability by using Cronbach alpha coefficient and composite reliability (CR) with standards above 0.70 (Singh and Sharma, 2016). If the Cronbach alpha coefficient between 0.7 and 0.8 , internal consistency could be considered as good. If above 0.8 , then it was considered as very good. The test results showed that the Cronbach alpha and CR coefficients of all constructs were above 0.70 . Thus, the constructs used had good reliability.

\section{SEM Analysis and Hypothesis Test}

After went through a series of analyzing as described above, the next step was to confirm the proposed research hypothesis. The test results in Table 2 shown that Total Quality Management significantly gave a positive influence on the company's business performance with path coefficient was 1.81 and $t$-value 4.169 with probability value was less than 0.001 . This meant that the proposed hypothesis was in accordance with the test results. In addition, the constructs of TQM variable and company's business performance showed very satisfying results. The value of entire constructs variable was positive with t-values ranging from 2.845 to 4.189 and path coefficients ranging from 0.552 to 1.814 with probability values was less than 0.05 , meant that the constructs used to measure and assess the extent to which its ability to represent both variables had been fulfilled. Thus, the practice of TQM had a real impact on business performance of PT. XYZ. It was in accordance with the research conducted by Panuwatwanich and Nguyen (2017); Singh et al. (2018); and Vasantharayalu and Pal (2016), that the practices of TQM could fixed and generated company performance to dominate the status. The company must be certain that with consistency in the matters of continuous improvement as well as empowering employees by including them in each training and self-development could gave a positive impact on company's sustainability. Competitive advantage was not impossible if the company maintained the principles that had been built.

\section{Managerial Implications}

The practical implications of Total Quality Management (TQM) were able to improve and enhance company performance. By the results obtained were proven that there was a significant positive effect of TQM practices on company business performance. Focus on customers, obsession of quality, scientific approach, employee empowerment, teamwork, continuous improvement, education and training, controlled freedom, unity of purpose, employee engagement and empowerment were TQM sets of dimensions. Not only oriented on customer satisfaction or providing training and education for employees, but TQM also proposes continuous improvement for company, so that the targets and ideals can be realized. Thus, companies that have implemented TQM practices are consistent and comprehensive. Meanwhile, companies that still practicing traditional management are encouraged to immediately move to TQM. 


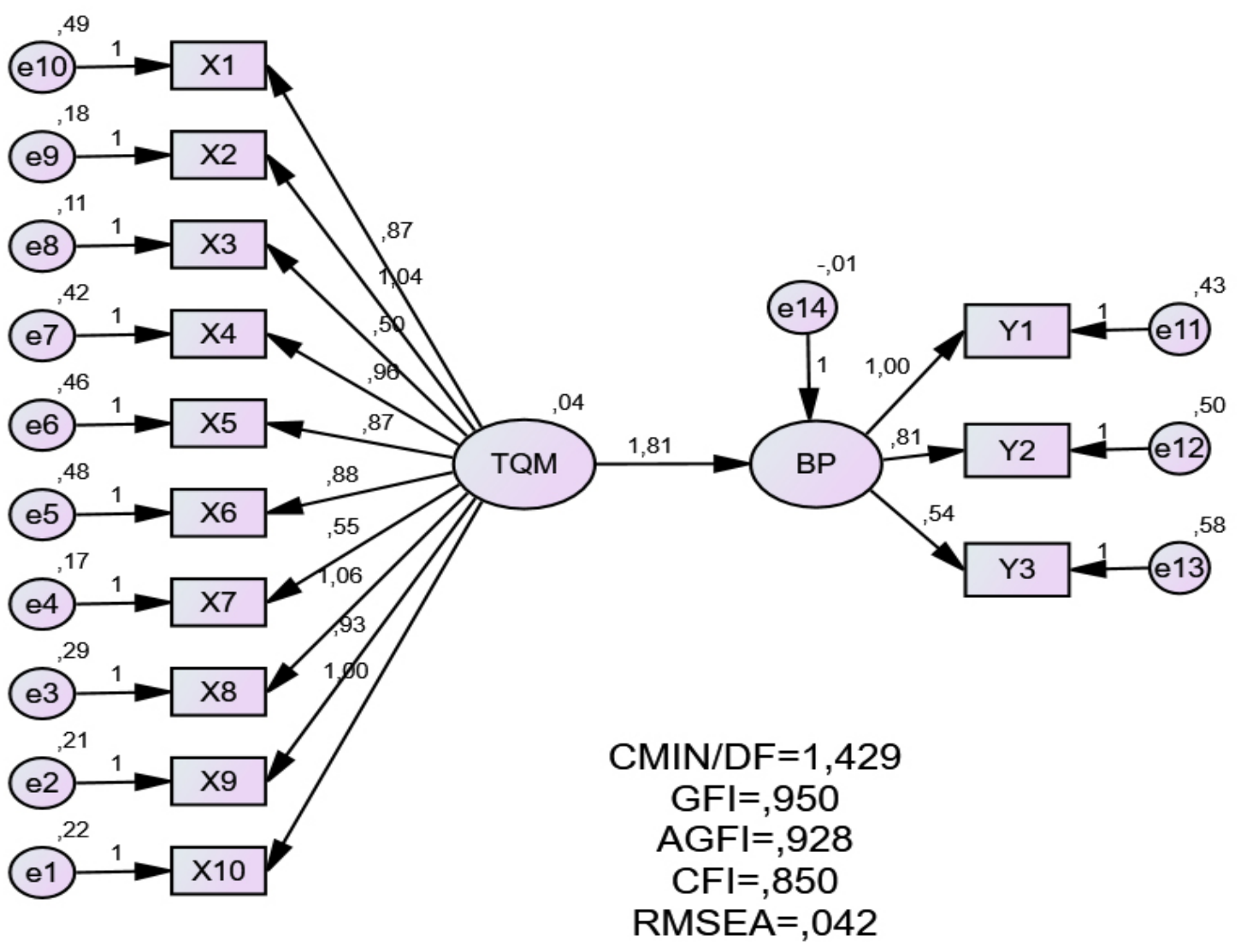

Figure 3. Tes result of SEM model between TQM and BP

Tabel 3. The result of hypothesis test

\begin{tabular}{lllll}
\hline Hypothesis & Path coefficient & t-value & P-value & Result \\
\hline $\begin{array}{l}\text { TQM significantly had positive effect on company's business } \\
\text { performance }\end{array}$ & 1,024 & 4,169 & $* * *$ & Accept \\
\hline
\end{tabular}

\section{CONCLUSIONS AND RECOMMENDATIONS}

\section{Conclusions}

Total Quality Management (TQM) was one of management quality improvement strategies that had been proven to be able to give a positive effect on company performance significantly, as proved by practitioners and academics. In accordance with the statement, this research also proved that the implication of TQM with its 10 indicators such as focus on customers, obsession with quality, scientific approach, empowerment of employees, teamwork, continuous improvement, education and training, controlled freedom, unity of purpose, and involvement and empowerment of employees significantly gave positive effect on company business performance of PT. XYZ consisted of Return on Investment (ROI), market share, and sales growth, with the value of path coefficient is 1.81 , and the t-value by 4.169 with probability value less than 0.001 . This proved that in improving the quality of company management should adopt the TQM concept that covered the success of almost all aspects of company's business. Not only oriented to customer satisfaction or provided training and education to employees, TQM also proposed continuous improvement to the company so that the goals and ideals could be realized. These results had a positive impact on the company, that if TQM practices were applied seriously, it will provide optimal results, and not impossible for companies to be able to achieve competitive advantages. Theoretically, it was able to add value to the relationship between TQM concepts and the company's business performance, planned measurement indicators according to priority improvements, and minimized more specific gaps. 


\section{Recommendations}

For further researches, to add mediation variables is recommended, as well as to investigate the relationship of TQM with other aspects, such as leadership, transformation, and information in the relationship of company performance. Furthermore, in order to obtain a more general picture and enrich the knowledge about the effectiveness of TQM practice, further investigations regarding TQM practices on business performance of similar manufacturing companies are recommended.

\section{REFERENCES}

Abbas J. 2020. Impact of total quality management on corporate sustainability through the mediating effect of knowledge management. Journal of Cleaner Production 244: 1-11. doi: 10.1016/j. jclepro.2019.118806.

Al-Dhaafri HS, Al-Swidi AK, Yusoff RZ. 2016. The mediating role of total quality management between the entrepreneurial orientation and the organizational performance. TQM Journal 28(1). doi: 10.1108/TQM-03-2014-0033.

del Alonso-Almeida MM, Bagur-Femenías L, Llach J. 2015. The adoption of quality management practices and their impact on business performance in small service companies: the case of Spanish travel agencies. Service Business 9(1): 57-75. doi: 10.1007/s11628-013-0218-6.

Arbuckle JL. 2013. IBM SPSS Amos 22 User's Guide. New York: IBM Corp.

Bolboli SA, Reiche M. 2013. A model for sustainable business excellence: Implementation and the roadmap. The TQM Journal 5 (4): 331-346.

Cancino CALa Paz AI, Ramaprasad A, Syn T. 2018. Technological innovation for sustainable growth: An ontological perspective. Journal of Cleaner Production 179: 31-41. doi: 10.1016/j. jclepro.2018.01.059.

Cetindere A, Duran C, Yetisen MS. 2015. The effects of total quality management on the business performance: An application in the province of Kütahya. Procedia Economics and Finance 23: 1376-1382. doi: 10.1016/s22125671(15)00366-4.

Delić M, Radlovacki V, Kamberovic B, Maksimovic R, Pecujlija M. 2014. Examining relationships between quality management and organisational performance in transitional economies. Total Quality Management and Business Excellence 25(3-4): 367-382. doi: 10.1080/14783363.2013.799331.

Gaspersz V. 2001. Total Quality Management. Revisi. Jakarta: Gramedia Pustaka Utama.

Gherardini F, Renzi C, Leali F. 2017. A systematic user-centred framework for engineering product design in small- and medium-sized enterprises (SMEs). International Journal of Advanced Manufacturing Technology 91(5-8): 1723-1746. doi: 10.1007/s00170-016-9857-9.

Hair JF, Black WC, Babin BJ, Anderson RE. 2010. MultivariateDataAnalysis: a GlobalPerspective. Edited by 7. London: Pearson Education.

Ibidunni AS, Salau OP, Falola HO, Ayeni AW, Obunabor FI. 2017. Total quality management and performance of telecommunication firms. International Business Management 11(2): 293298. doi: 10.3923/ibm.2017.293.298.

Jaca C, Psomas E. 2015. Total quality management practices and performance outcomes in Spanish service companies. Total Quality Management and Business Excellence 26(9-10): 958-970. doi: 10.1080/14783363.2015.1068588.

Jimoh R, Oyewobi L, Isa R, Waziri I. 2019. Total quality management practices and organizational performance: the mediating roles of strategies for continuous improvement. International Journal of Construction Management 19(2): 162-177. doi: 10.1080/15623599.2017.1411456.

Kafetzopoulos DP, Psomas EL, Gotzamani KD. 2015. The impact of quality management systems on the performance of manufacturing firms'. International Journal of Quality and Reliability Management 32(4): 381-399. doi: 10.1108/ IJQRM-11-2013-0186.

Kannan VR, Tan KC. 2005. Just in time, total quality management, and supply chain management: Understanding their linkages and impact on business performance. Omega 33(2): 153-162. doi: 10.1016/j.omega.2004.03.012.

Khanna VK, Gupta R. 2014. Comparative study of the impact of competency-based training on 5 "S" and TQM: A case study. International Journal of Quality and Reliability Management 31(3): 238260. doi: 10.1108/IJQRM-12-2012-0163.

Mahmood HK, Hashmi MS, Shoaib M, Danish R, Abbas J. 2014. Impact of TQM practices on motivation of teachers in secondary schools empirical evidence from Pakistan. Journal of Basic and Applied Scientific Research 4(6): 1-8. 
Available at: www.textroad.com.

Konecny PA, Thun JH. 2011. Do it separately or simultaneously - An empirical analysis of a conjoint implementation of TQM and TPM on plant performance', International Journal of Production Economics 133(2), pp. 496-507. doi: 10.1016/j.ijpe.2010.12.009.

Kumar R, Garg D, Garg TK. 2011. TQM success factors in North Indian manufacturing and service industries. TQM Journal 23(1): 36-46. doi: 10.1108/17542731111097470.

Lamb CW, Hair JF, McDaniel, C. 2001. Pemasaran. 5th edn. Jakarta: Salemba Empat.

Li D, Zhao Y, Zhang L, Chen X, Cao C. 2018. Impact of quality management on green innovation. Journal of Cleaner Production 170: 462-470. doi: 10.1016/j.jclepro.2017.09.158.

Maheshwari S, Vohra V. 2015. Identifying critical HR practices impacting employee perception and commitment during organizational change. Journal of Organizational Change Management 28(5): 872-894. doi: 10.1108/JOCM-03-20140066.

Maruyama GM. 1998. Basics of Structural Equation Modeling. USA: SAGE Publications, Inc. doi: http://dx.doi.org/10.4135/9781483345109.

Mensah JO, Copuroglu G, Fening FA. 2012. The status of total quality management (TQM) in Ghana. A comparison with selected quality awards winners from Turkey. International Journal of Quality \& Reliability Management 29(8): 851-871. Doi: https://doi.org/10.1108/02656711211270333.

Panuwatwanich K, Nguyen TT. 2017. Influence of organisationalcultureontotalqualitymanagement implementation and firm performance: evidence from the vietnamese construction industry. Management and Production Engineering Review 8(1): 5-15. doi: 10.1515/mper-20170001.

Parvadavardini S, Vivek N, Devadasan SR. 2016. Impact of quality management practices on quality performance and financial performance: evidence from Indian manufacturing companies. Total Quality Management and Business Excellence 27(5-6): 507-530. doi: 10.1080/14783363.2015.1015411.

Prajogo DI, Sohal AS. 2006. The integration of TQM and technology/R\&D management in determining quality and innovation performance. Omega 34(3): 296-312. doi: 10.1016/j. omega.2004.11.004.
Richard PJ, Devinney TM, Yip GS, Johnson G. 2009. Measuring organizational performance: Towards methodological best practice. Journal of Management 35(3): 718-804. doi: 10.1177/0149206308330560.

Sahoo S, Yadav S. 2017. Effectiveness of Lean Manufacturing Technologies on Improving Business Performance: a study of Indian manufacturing industries. International Journal of Social, Behavioral, Educational, Economic, Business and Industrial Engineering 11(2): 362369.

Sahoo S, Yadav S. 2018. Total quality management in Indian manufacturing SMEs', Procedia Manufacturing 21: 541-548. doi: 10.1016/j. promfg.2018.02.155.

Salas-Arbeláez L, García Solarte M, Murillo Vargas G. 2017. Efecto de la cultura organizacional en el rendimiento de las PYMES de Cali, Suma de Negocios 8(18): 88-95. doi: 10.1016/j. sumneg.2017.11.006.

Shafiq M, Lasrado F, Hafeez K. 2019. The effect of TQM on organisational performance: empirical evidence from the textile sector of a developing country using SEM. Total Quality Management and Business Excellence 30(1-2): 31-52. doi: 10.1080/14783363.2017.1283211.

Singh V, Kumar A, Singh T. 2018a. Impact of TQM on organisational performance: The case of Indian manufacturing and service industry. Operations Research Perspectives 5: 199-217. doi: 10.1016/j. orp.2018.07.004.

Singh V, Sharma SK. 2016. Analyzing the moderating effects of respondent type and experience on the fuel efficiency improvement in air transport using structural equation modeling. European Transport Research Review 8(2): 12. doi: 10.1007/s12544-016-0199-3.

Sinha N, Dhall N. 2018. Mediating effect of TQM on relationship between organisational culture and performance: evidence from Indian SMEs. Total Quality Management \& Business Excellence 0(0): 1-25. doi: 10.1080/14783363.2018.1511372.

Small EP, Ayyash L, Hamouri K. 2017. Benchmarking performance of TQM principals in electrical subcontracting in Dubai: A case study. Procedia Engineering 196: 622-629. doi: 10.1016/j. proeng.2017.08.050.

Syamsuddin L. 1992. Manajemen Keuangan Perusahaan. Jakarta: CV Rajawali.

Tjiptono F, Diana A. 2003. Total Quality Management. 
5th edn. Yogyakarta: Andi Offset.

Vasantharayalu, Pal S. 2016. An empirical study of Total Quality Management (TQM) practices on operational performance of indian manufacturing and service firms. International Journal of Management (IJM) 7(6): 192-202.

Wagimin, Kusrini E, Ali J, Helia VN. 2019. The effect of leadership on employee performance with Total Quality Management (TQM) as a mediating variable in Indonesian petroleum companies: A case study. International Journal of Integrated Engineering 11(5): 180-188. doi: 10.30880/ ijie.2019.11.05.023.
Yang J, Wong CWY, Lai KH, Ntoko AN. 2009. The antecedents of dyadic quality performance and its effect on buyer-supplier relationship improvement', International Journal of Production Economics 120(1): 243-251. doi: 10.1016/j.ijpe.2008.07.033.

Zakuan NM, Yusof SM, Laosirihhongthong T, Shaharoun, AM. 2010. Proposed relationship of tqm and organisational performance using structured equation modelling. Total Quality Management and Business Excellence 21(2): 185-203. doi: 10.1080/14783360903550020. 